Winter 2007

\title{
Globalization of Legal Practice in the Internet Age
}

Leonard Bierman

Texas A\&M University

Michael A. Hitt

Texas A\&M University

Follow this and additional works at: https://www.repository.law.indiana.edu/ijgls

Part of the International Law Commons, Internet Law Commons, and the Legal Profession Commons

\section{Recommended Citation}

Bierman, Leonard and Hitt, Michael A. (2007) "Globalization of Legal Practice in the Internet Age," Indiana Journal of Global Legal Studies: Vol. 14 : Iss. 1 , Article 3.

Available at: https://www.repository.law.indiana.edu/ijgls/vol14/iss1/3

This Symposium is brought to you for free and open access by the Law School Journals at Digital Repository @ Maurer Law. It has been accepted for inclusion in Indiana Journal of Global Legal Studies by an authorized editor of Digital Repository @ Maurer Law. For more information, please contact rvaughan@indiana.edu.

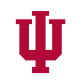

JEROME HALL LAW LIBRARY

INDIANA UNIVERSITY

Maurer School of Law
Bloomington 


\title{
The Globalization of Legal Practice in the Internet Age
}

\author{
Leonard Bierman* and Michael A. Hitt**
}

\begin{abstract}
The Internet's global reach has had a significant impact on the legal profession. This essay explains a few of the key developments in this area, including: competition fueled by outsourcing legal work to lower-wage earning lawyers around the world, "virtual work" changing client interaction and attorney work schedules, law firm reputation as a result of information availability on the Internet, work-product monitoring and the commoditization of legal services, and workforce diversity spurred by the influence of international clients.
\end{abstract}

\section{INTRODUCTION}

We live in the age of the Internet. New York Times columnist Thomas L. Friedman made this point forcefully in his recent best-selling book The World Is Flat: A Brief History of the Twenty-First Century.' The Internet's "flattening" of the world has had a significant impact on the legal profession, as discussed by various observers at this Journal's recent conference, Globalization of the Legal Profession. ${ }^{2}$ This essay explains a few of the key developments in this area.

\section{Global Competition}

Today we live in a world of global trade and commerce, and lawyers, along with other American workers, are increasingly competing with workers from

*Professor of Management, Mays Business School, Texas A\&M University.

**Distinguished Professor of Management, Mays Business School, Texas A\&M University.

1. See generally Thomas L. Friedman, The World Is Flat: A Brief History of the TwentyFirst Century (2005) (discussing the ways in which the Internet has "flattened the world" and affected the ways businesses operate).

2. See Symposium, Globalization of the Legal Profession, 14 Ind. J. Global Legal Stud. 1 (2007).

Indiana Journal of Global Legal Studies Vol. 14 \#1 (Spring 2007)

CIndiana University School of Law 
other countries. For example, three of the five largest (based on revenues) law firms in the world are headquartered in the United Kingdom (i.e., Clifford Chance, Freshfields, and Linklaters), and each of these firms has over half of its lawyers located in various foreign countries. ${ }^{3}$ Moreover, there is an increasing trend, as Thomas Friedman predicted, ${ }^{4}$ to outsource (via the Internet) basic legal research and document preparation to lower-wage earning lawyers in Englishspeaking India. ${ }^{5}$ Indeed, as Professor Jayanth Krishnan recently documented, the range of legal work being exported to India has steadily increased in recent years. ${ }^{6}$ At all levels of work, U.S. lawyers are facing ever growing global competition fueled at least in part by Internet technology.

\section{24/7 WORKLIFE AND VIRTUAL WORK}

Remember the days before e-mail and the Internet? Remember the days when leaving the office truly meant "leaving the office"? Those days are gone! Today the world has approximately 700 million adult Internet users, with 152 million of those living in the United States. ${ }^{7}$ E-mail and related "work flow software" such as Blackberrys literally make it possible to "be at work" on a $24 / 7$ basis. ${ }^{8}$ Time zone barriers, for example, that once gave U.S. attorneys with overseas clients some defined "off-time" from direct client interaction have largely been eliminated. Today a client or co-worker can send an e-mail from Moscow to New York at any time, with the expectation of a fairly quick response. Similarly, work files, draft documents, etc., can be sent back and forth via the Internet to virtually anywhere in the world. Cell phones allow individuals to be reached with ease even when they are not in the office or at a computer. ${ }^{9}$ Being an attorney, especially one with an internationally oriented practice, is increasingly becoming a 24/7 occupation.

3. See Michael A. Hitt, Leonard Bierman \& Jamie D. Collins, The Strategic Evolution of Large U.S. Law Firms, 50 Bus. Horizons (forthcoming Jan.-Feb. 2007) (manuscript at 5 tbl. 2, on file with authors).

4. See Friedman, supra note 1, at 239.

5. See generally Jayanth K. Krishnan, Outsourcing and the Globalizing Legal Profession, 48 WM. \& MARY L. Rev. (forthcoming 2007) (discussing legal outsourcing using the United States and India as case studies).

6. Id.

7. Oliver Ryan, Leading Indicators: A Compendium of Revealing Stats, Fortune, May 29, 2006, at 19.

8. See Friedman, supra note 1, at 71-81.

9. See id. at 213. 
The reverse side of the Internet's $24 / 7$ demands, however, is that "virtual work" has become increasingly accepted in the profession (and by clients as well). A growing number of law firms have begun offering attorneys the opportunity to work part-time or from home for part of the week. ${ }^{10}$ That said, only 3 to 4 percent of lawyers currently take advantage of this option, and male attorneys tend to be particularly reluctant to adopt such a work schedule. " Potential "stigmatization" appears to be of concern here; attorneys believe that even if the firm's management says that a flexible work schedule is acceptable, adoption of such a work schedule may still be perceived as a lack of the attorney's commitment to the firm. ${ }^{12}$ Moreover, management researchers have found that employees on "nonstandard" work arrangements can at times cause resentment and other problems in the workforce. ${ }^{13}$ Consequently, it remains unclear to what extent "virtual work" is likely to emerge as a major factor in the legal profession.

\section{III. "BE Good"}

In the second edition of his book, published in 2006, Thomas Friedman added a clever section entitled "Be Good." 14 In this section, Friedman cautions readers to live their lives "honestly, because whatever you do, whatever mistakes you make, will be searchable one day." Internet as a whole, has had a tremendous impact on the amount of information publicly available about lawyers and law firms. While not required to report to the SEC, the nation's largest law firms have in many respects become quasi-public entities. Trade publications such as American Lawyer gather and annually publish, on the Internet and elsewhere, extensive financial data about these firms, and academic researchers conduct comprehensive analyses using these data. ${ }^{16}$ Internet

10. Marci Alboher Nusbaum, Lawyers Push to Keep the Office at Bay, N.Y. Times, Sept. 7, 2003, $\S 3$, at 13 .

11. Hitt, Bierman \& Collins, supra note 3 , at 8 .

12. Id.

13. See generally Joseph P. Broschak \& Alison Davis-Blake, Mixing Standard Work and Nonstandard Deals: The Consequence of Heterogeneity in Employment Arrangements, 49 ACAD. MGmт. J. 371 (2006) (discussing a study that examines how proportions of individuals in standard and nonstandard work arrangements affect workplace relationships).

14. Thomas L. Friedman, The World Is Flat: A Brief History of the Twenty-first CenTURY 185-86 (1st updated and expanded ed. 2006).

15. Id. at 185.

16. See, e.g., William D. Henderson, An Empirical Study of Single-Tier Versus Two-Tier Partnerships in the Am Law 200, 84 N.C. L. Rev. 1691 (2006); Michael A. Hitt et al., Direct and Moderating 
"blogs" such as Silicon Valley Media Law, ${ }^{17}$ Legal Sanity, ${ }^{18}$ and Adam Smith, Esq. ${ }^{19}$ update and extend this information on an almost daily basis. Law firm reputations and the reputations of their attorneys are now almost constantly "in play."

In many ways this change mirrors what organizational theorists have noted as the shift in large law firms away from a "professional," or so-called P-2 model, to that of a traditional "corporate business" or "Managerial Professional Business" model. ${ }^{20}$ Most of the current large law firms no longer act as true "partnerships,"21 and they certainly no longer enjoy any shroud of partnership secrecy. Whatever problems or successes they may experience, the Internet, particularly via blogs, ensures that their competitors, even overseas competitors, and others will find out about them in short order. In such a context, and with their reputations constantly on the line, law firms and attorneys are indeed best off following Thomas Friedman's advice to "Be Good"!

\section{Work-Product Monitoring and Work-Product Commoditization}

Computer and Internet technology has made it increasingly easy for all types of firms to monitor their supply chain and production cycle. In the case of law firms, clients such as E.I. du Pont de Nemours and Company ${ }^{22}$ can use this technology to carefully scrutinize services billed to ensure that they receive full value for every dollar of outside legal services purchased.

Moreover, the Internet and related technologies are helping to make the practice of law more and more of a commodity type of business. ${ }^{23}$ Once-complicated

Effects of Human Capital on Strategy and Performance of Professional Service Firms: A ResourceBased Perspective, 44 Acad. MGmт. J. 13 (2001).

17. Silicon Valley Media Law Blog, http://www.svmedialaw.com (last visited Apr. 10, 2007).

18. Legal Sanity by Arnie Herz, http://www.legalsanity.com (last visited Apr. 10, 2007).

19. Adam Smith, Esq., http://www.bmacewen.com/blog (last visited Apr. 10, 2007).

20. See David J. Cooper, Bob Hinings, Royston Greenwood \& John L. Brown, Sedimentation and Transformation in Organizational Change: The Case of Canadian Law Firms, 17 OrG. Stud. 623, 625, 635 (1996).

21. See Leonard Bierman \& Rafael Gely, So, You Want to Be a Partner at Sidley \& Austin?, 40 Hous. L. Rev. 969, 970-71 (2003).

22. See Sarah Kellogg, The Business of Law, WAsh. Law, Oct. 2005, at 23, 24, for a discussion outlining how the DuPont Corporation and other companies are increasingly playing "hardball" in terms of monitoring law firm billings to make sure they receive appropriate value for every dollar spent.

23. See generally George P. Baker \& Rachel Parkin, The Changing Structure of the Legal Services Industry and the Careers of Lawyers, 84 N.C. L. Rev. 1635 (2006) (discussing a shift toward a com- 
legal research tasks are now accomplished with relative ease using computers and electronic files and records. As a result, these searches are increasingly completed by in-house corporate legal departments rather than farmed out to expensive outside law firms. ${ }^{24}$ Exclusive corporation/law firm relationships of days of old (e.g., the long-standing relationship between Chase Manhattan Bank and the bluechip Milbank Tweed law firm in New York City) ${ }^{25}$ are literally being replaced by corporate online auctions for legal services. ${ }^{26}$ For example, in 2004 General Electric Corporation began using a web-based provider of strategic e-sourcing solutions, "procuri.com," major law firms could competitively bid to provide specific legal services to GE. ${ }^{28}$ Procuri.com has been called the "Priceline.com" for large law firms. As NYU Law Professor Geoffrey P. Miller has recently pointed out, the old days of "clubby" law firm/client relations are clearly no longer the rule in the current Internet world. ${ }^{29}$

\section{Workforce Diversity}

Finally, it should be noted that the Internet and related technology has made it possible for law firms to do work for clients throughout the world even without a physical presence in given countries, and this development may have an impact on increasing attorney diversity in U.S. law firms. In recent years, major corporations have increasingly pressured their law firms to have a diverse attorney workforce for "market-based" 30 and other reasons. ${ }^{31}$ For example, Wal-Mart Corporation recently informed its leading outside law firms that at least "one person of color and one woman" must be among the top "relationship attorneys"

modity relationship and an increased reliance on business-getting in the legal services industry).

24. See id. at 1654-55.

25. Id. at 1654-55 n.41.

26. See Anthony Lin, Like Any Vendor, Law Firms Are Asked to Compete for Business on the Web, N.Y. L.J., Nov. 6, 2003, at 1.

27. See Procuri.com, Supply Management Excellence on Demand, http://www.procuri.com (last visited Oct. 5, 2006).

28. Lin, supra note 26.

29. Geoffrey Miller, From Club to Market: The Evolving Role of Business Lawyers, 74 Fordha m L. REv. 1105, 1111 (2005).

30. See David B. Wilkins, From "Separate Is Inherently Unequal" to "Diversity Is Good For Business": The Rise of Market-Based Diversity Arguments and the Fate of the Black Corporate Bar, 117 Harv. L. Rev. 1548, 1554-58 (2004).

31. See Karen Donovan, Pushed by Clients, Law Firms Step Up Diversity Efforts, N.Y. Times, July 21,2006 , at C6. 
handling its business, ${ }^{32}$ and Sara Lee Corporation and other major companies have taken similar actions. ${ }^{33}$ In many foreign countries corporate diversity has recently become an even greater priority than in the United States. For example, Norway and Spain will soon require that women hold at least 40 percent of all corporate board of director seats. ${ }^{34}$ Thus, to the extent large U.S. law firms represent multi-billion dollar Norwegian companies like Norsk Hydro and Statoil, or Spanish companies like Repsol, these companies may bring greater pressure for diversity, especially senior-level female diversity, in these law firms.

\section{Conclusion}

The Internet's "flattening" effects are certainly being felt by the legal profession across numerous dimensions. In particular, the Internet has hastened the profession's globalization. Traditional time and location barriers have largely been eliminated in the Internet age. That said, the elimination of these barriers has also made the practice of law more competitive, with the full impact of this unbridled competition yet to be seen.

32. Meredith Hobbs, Wal-Mart Demands Diversity in Law Firms, Fulton County Daily ReP., July 6, 2005, http://www.law.com/jsp/article.jsp? id =1120579809481.

33. Id.

34. Charles Penty, Spain Tries to Counter Corporate Machismo, Hous. Chron., July 28, 2006, at D8. 